\title{
OSCAR K
}

\section{En vindhat i Prag}

Blæsten brølede lydløs og kold over Karlsbroen. Rækker af stenkopier med forvitrede næser: Sankt Ives, Pieta, Norbert, Wenceslas og Sigismund. Sankt Adalbert. Ikke en levende sjæl. Vinden bed i kinderne. Myrtegrene, hvide silketørklæder og visne brudebuketter føg som nedfaldne blade hen ad de blanke brosten. Herreløse hatte. Jeg samlede én op og undrede mig over, hvor nøjagtigt den passede, til trods for at jeg har en højst ejendommelig hovedform.

Jeg havde siddet og skrevet hele natten. Rilke gjorde det mod frygten. Jeg ved ikke, hvad jeg gjorde det for. Ana var taget til Lissabon til sin svigermor og minderne. Og selv har jeg ingen og intet og rejser rundt $i$ verden med en kuffert og en kasse bøger uden egentlig at være nysgerrig. Hvad er det $i$ grunden for et liv: uden hus, uden nedarvede ting, uden hunde? Havde jeg da i det mindste en hund...

Jeg gik efter lyden. Ind i Karlova med hatten på som en anden shandy. Armenierens kaffehus var stænget, Vacekpladsen tom. Det var en næsten uhørlig tone, som kom den fra et savblad eller en flaske muret ind $i$ en skorsten. Jeg havde rejst mig for at strække benene, da jeg blev opmærksom på den. Først troede jeg, den kom ude fra gangen, at en eller anden havde glemt at lukke et vindue eller en dør, men alt var stille som i graven. Skulle mine ører have spillet mig et puds? Det var ikke første gang, der skete mærkelige ting i alkymisternes labyrinter.

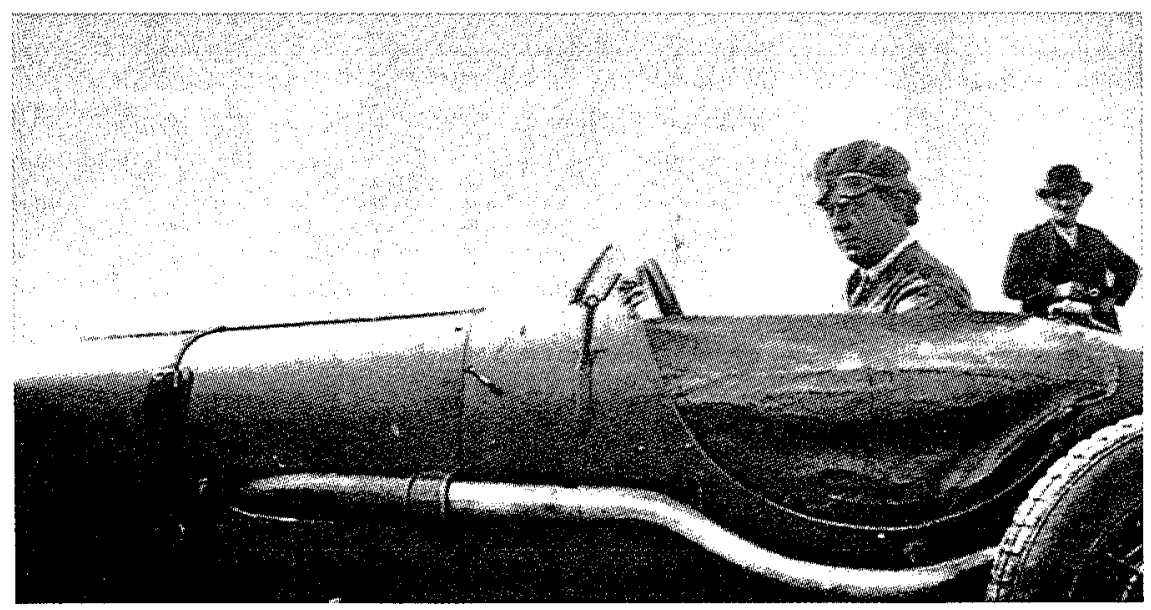


Skip Canell havde siddet ved sit improviserede skrivebord i en pension i det gamle jødekvarter, da døren til værelset blev åbnet. Han drejede sig rundt og så en skikkelse komme ind og sætte sig ved bordet med hovedet hvilende i hænderne. Den begyndte at diktere. Såan tilbragte de timevis, til Canell vovede at spørge, hvem den var. Den sagde, den var sabelsluger og især holdt af dolke. I pensionens spisesal skete der noget forfærdeligt: den arme sabelsluger fik en gaffel i den gale hals, og Skip Canell måtte køre den på hospitalet, hvor overlægen kirurgisk fjernede gaflen. Siden så han ikke sabelslugeren mere, men havde en fornemmelse af, at den flagrede omkring og kunne dukke op, hvad øjeblik, det skulle være.

Ramón Gómez de la Serna opdagede, at han til forveksling lignede sin far, når han på hotelværelset så sig i spejlet. Er jeg måske min far? Er mit liv intet andet end en fantasi under falsk navn? Vil vi altid blot være forfædre og aldrig os selv?, spurgte han sig og knuste med en vild latter spejlet.

Og de var ikke de eneste, der var ved at miste forstanden $\mathrm{i}$ byen med de hundrede tårne. Gombrowicz, der var overbevist om, at der ikke findes nogen flugt fra den situation, et menneske befinder sig i - situationen former dit fjæs! - fandt en dag følgende notits fra Stephan Zenith, som han delte værelse med:

“... jeg tager væk fra Prag, jeg er bekymret for mit liv, jeg har en fornemmelse af, at der bor en sort lejer inden i mig - ja, sommetider sammen med mig, en garnspole, der făr mig til at sige ting, som jeg ikke tænker og aldrig kunne finde på. Den er stjerneformet med strittende uldtotter. Der stikker en lille pind ud fra midten, så den kan støtte på dén og en af stjernespidserne, og når jeg kommer ud af døren, står

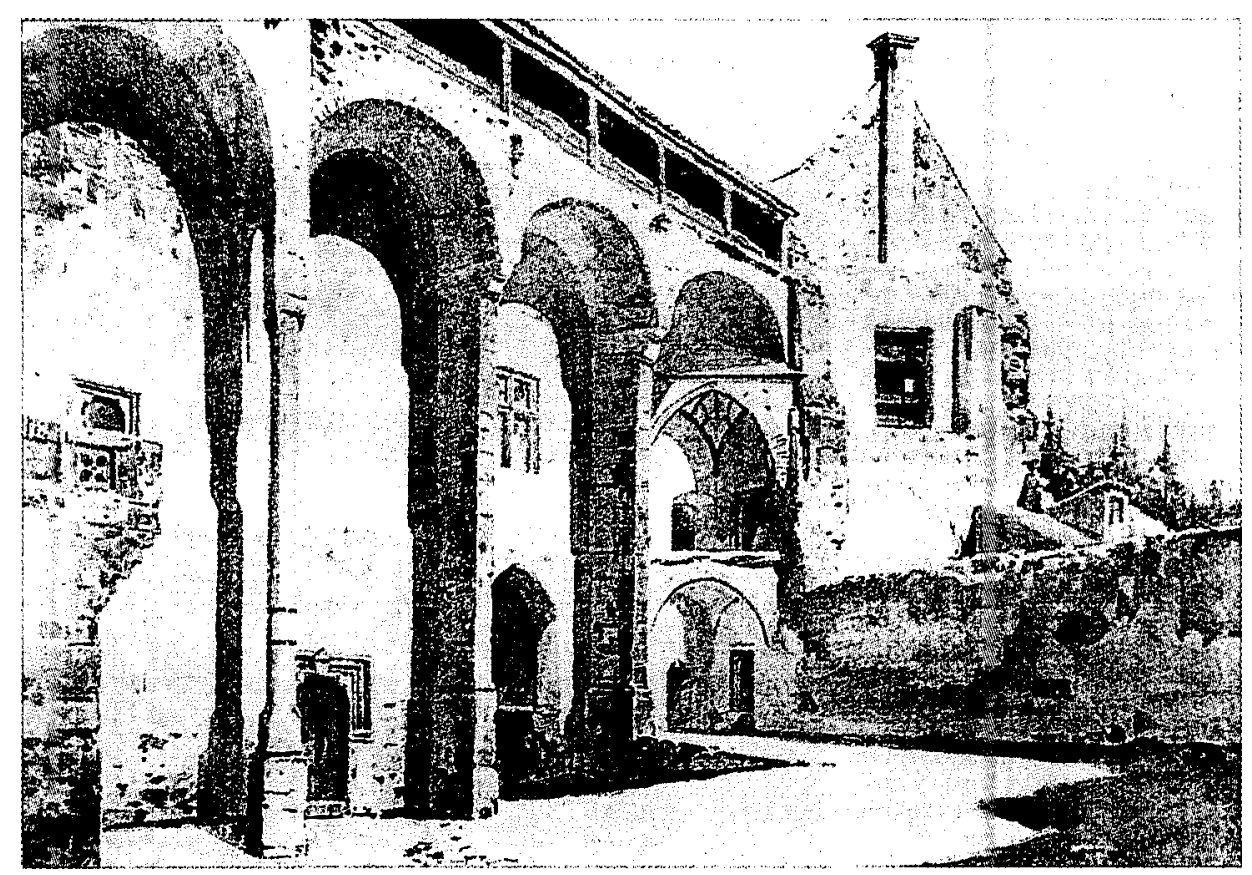


den og læner sig op ad gelænderet, så jeg får lyst til at tale med den. Jeg stiller naturligvis ikke svære spørgsmål, men f. eks.: Hvad hedder du? Odradek, siger den. Og hvor bor du? Bopæl ubekendt, siger den og ler. Men det er en latter frembragt uden lunger, som raslen fra nedfaldende blade. Jeg er bange, Withold ... jeg tager væk."

Det er næppe nogen tilfældighed, at garnspolens løjerlige navn for alle shandier herefter blev ensbetydende med sort lejer. Som følge af et tæt samliv med deres dobbeltgængere, skjuler der sig i sande shandier en af disse sorte lejere, skyggeagtige væsener, som bor og gemmer sig i mørklagte sandheder, og hvis tanker og handlinger består af fragmenter uden sammenhæng. Odradekker.

Lugten af lindeblomster fra flodbredden fyldte de øde gader, let og fin. Staromistské námìsti. Rådhusuret slog to. "Die Nacht hat zwölf Stunden, dann kommt schon der Tag”. Skeletmanden ringede med klokken, nikkede tungt og løftede timeglasset, en karrig niding raslede med guldmønter i en pengepose, tyrken rystede på hovedet og forfængeligheden betragtede betaget sit spejlbillede.

Urmageren Hanuš var en lærd mand og lagde al sin glæde over nye opdagelser i uret. I byrådet frygtede man, at han ville give sin viden videre til andre byer, så en aften trængte hætteklædte mænd ind $\mathrm{i}$ hans hjem og blindede ham med gloende tænger foran kaminen. Hanuš sygnede hen, fordi han ikke længere kunne studere, men mandede sig endelig op og lod sig en dag bære hen til uret med et påskud om at få pendulet til at svinge lettere. I stedet ødelagde han urværket, vanviddet brød ud i lys lue, og han døde kort efter.

Blæsten havde lagt sig. Et eller andet sted i stilheden gemte lyden sig, svær at lokalisere. Som stumper af glemte sange i værtshusene. "Die Nacht hat zwölf Stunden, dann kommt schon der Tag ...". Skulle den virkelig komme fra U kalicha, værtshuset Bægeret, hvor den gode Havs ek lod kroværten Palivec have problemer med myndighederne, fordi fluerne havde overskidt billedet af kejseren og han havde taget det ned, og Švejk sætte sine venner stævne klokken atten efter krigen?

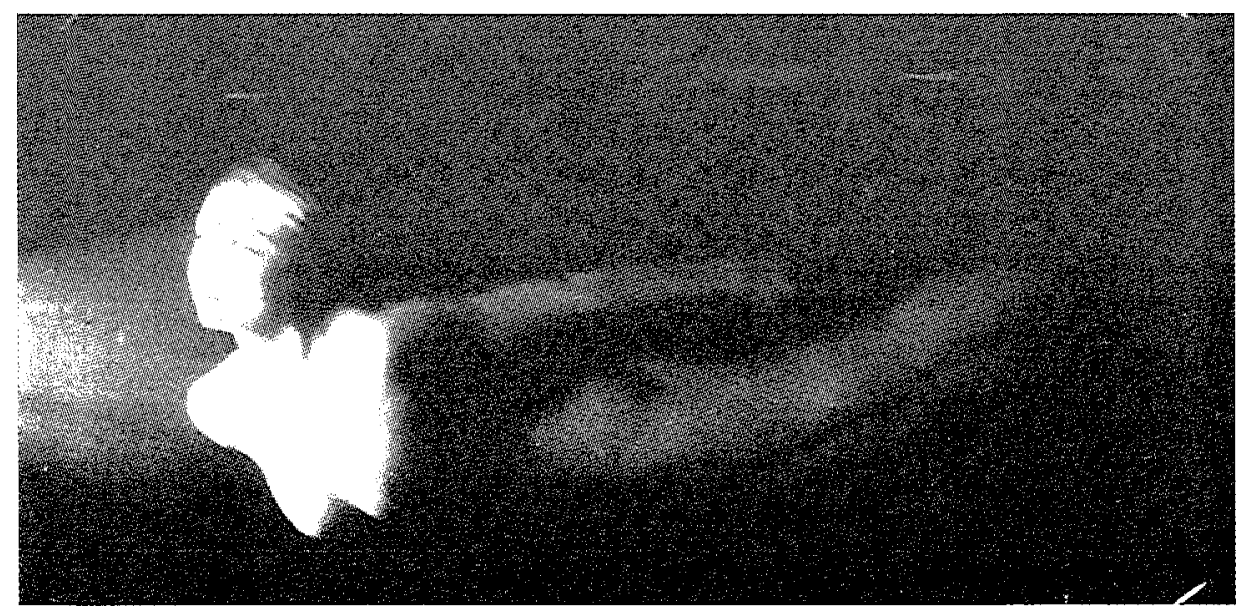


Han syntes, at de dage, han tilbragte på sindsygeanstalten, hørte til de bedste $\mathrm{i}$ hans liv, Švejk. Han var soldat og hundehandler. Mest hundehandler. Anas mand gik på militærakademiet, da de traf hinanden. Hun læste "Madame Bovary". Umådeholdent.

"Vi er i billardværelset", sagde hun. "Jeg tør sværge, at det var juli måned. Og vi siger alle de forbudte ord, begærligt, andægtige ..." Så var hun taget af sted. Hun brød sig ikke om Rilke. "Afkald og fravær ...”, hviskede hun med et bittert drag om munden.

Det var som om lyden var blevet til en susen, der trængte gennem vandrør og løb over tage og hjørner med mig. Bægeret var lukket. Ingen krovært. Ingen Svejk, der solgte bastarder af hunde med forfalskede stamtavler, som om de var ægte. Ingen historier om kreaturhandleren fra Boetislav, Ludvik Budijovice, som blev slået ihjel under et skænderi på markedet. Ingen Bretschneider. Ikke et øje. Kun denne susende hvisken, som toner fra et glasorgel, og lukkede, litterære værtshuse.

Bag ruderne i Café Arco stod stolene tomme omkring de runde borde. "Es werfelt und brodelt und kafkat und kitscht", hånede Karl Kraus i sin tid pragerkredsen. Her sad folkene fra avantgarden og kritiserede hinandens værker: Max Brod, Felix Weltsch og min navnebroder, den blinde Oscar Baum. Og Werfel var der, som mente, at kunsten er dødsfordriv - og Kafka. Denne akavede, magre mand, der aldrig synes at vokse ud af sin pubertetskrop. Trøstesløs tuberkuløs, neurotisk og kvindesky.

Og dog dukker et par feminint duftende navne op i dagbøger og breve. Felice Bauer, forsikringsagentdatter, som Kafka forlovede sig med - to gange. Grete Bloch, Felices veninde, diskret affære med følge: en dreng, som døde syv år gammel, uden at Kafka kendte til hans eksistens. Julie Wohryzek, sommerbekendtskab og hemmelig forlovelse. Dora Diamant, som Kafka levede sin sidste tid sammen med i en lejlighed i Berlins Steglitzkvarter. De studerede Thoraen og Talmud og lagde planer om at åbne en lille restaurant i Tel Aviv, Dora skulle stå i køkkenet, Kafka betjene gæsterne ...

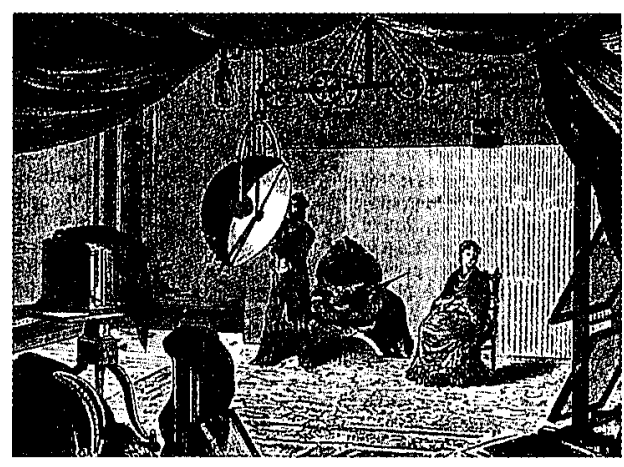


Og den mest fortryllende af dem alle: Milena Jesenská. Milena stammede fra Prag og boede i Wien og var ulykkeligt gift med pragerbohemen Ernst Polak, en notorisk potens pralrøv og kvindebedårer. Milenas far havde gjort hende arveløs på grund af ægteskabet med Polak, så hun tjente til dagen og vejen ved at skrive til aviser og oversætte bøger. Hun havde bedt Kafka om at måtte oversætte hans værker til tjekkisk og førte en længere korrespondence med ham. Den sky Kafka og den impulsive Milena begyndte at nære personlig interesse for hinanden, men han vægrede sig ved at mødes med den unge, gifte kvinde. Alligevel skete det til sidst $\mathrm{i}$ Wien, hvor de tilbragte et par ubesværede dage sammen. 9. Juni 1920 skrev Franz Kafka til Milena:

"Eftersom jeg elsker dig, elsker jeg hele verden, og til den hører også den venstre skulder og dit ansigt over mig i skoven og dit ansigt under mig i skoven og stilheden bagefter, når jeg lægger min kind mod dit næsten blottede bryst." Efter fotografiet at dømme har hun været spinkelt bygget, håret kraftigt, tørt og let kruset, mørke, intelligente, sørgmodige øjne, lille næse og en smukt formet mund.

Afkald og fravær. Dødsfordriv.

Jeg gik rundt på må og få i mine egne tanker. Brostenene blev våde og glatte. Det var begyndt at regne, jeg havde en fornemmelse af at være det eneste menneske i byen. Jeg var ikke helt klar over, hvor jeg var. Mit gamle bykort, som var overskrevet med nye navne: Most Legie, Jana Palacha, Masarykovo ... havde jeg ladet ligge på værelset. Regnen tog til og gadelygterne kastede diffuse skygger på mure og kantsten. Jeg standsede foran et vindue med voksmannequiner. De glatte hoveder kiggede på mig, nikkede, som kendte de mig. Pludselig var det som om gaderne blev levende, befolket af dukker i støvfrakker og med små kufferter og visne brudebuketter $\mathrm{i}$ hånden, usynlige robotter iført sorte hatte og hvide silketørklæder. De talte med hinanden på døvesprog og forsvandt parvis om hushjørner, bag plankeværker og op i nedløbsrør.

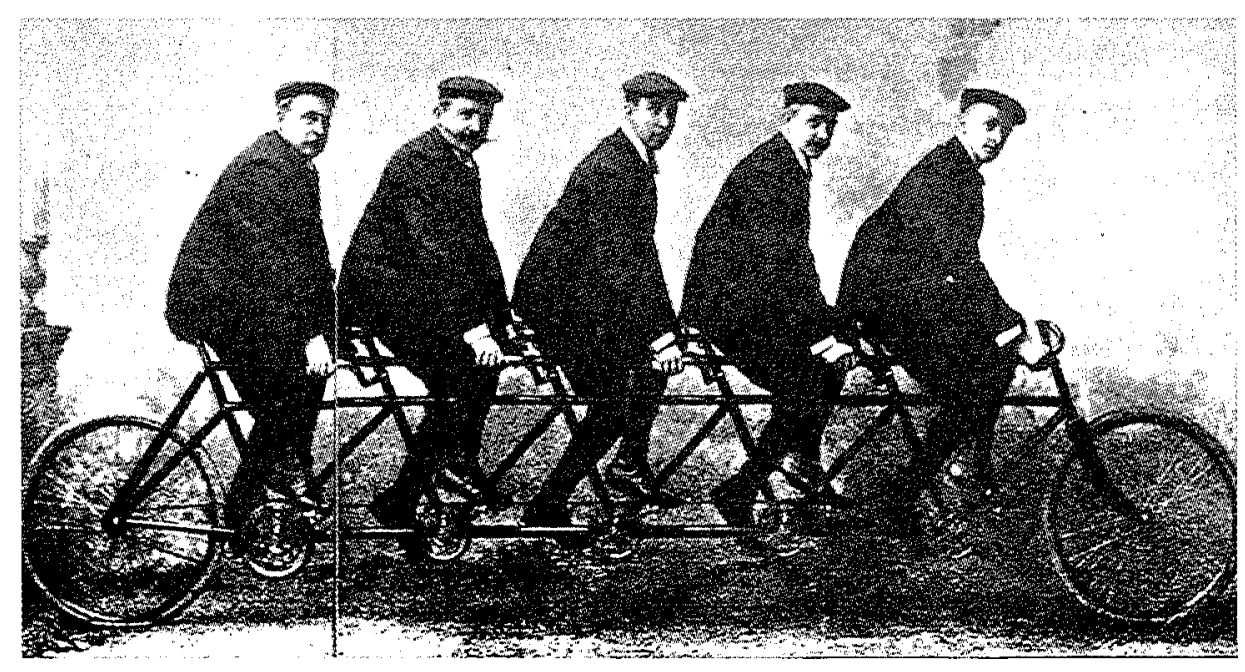


Ved indgangen til jødekvarteret på en stjerneformet, grønmalet lem stod en underlig skabning med en bulet blikskål foran sig på jorden. Han var kortklippet som en koncentrationslejrsfange, havde gråt fipskæg og var iført en gammelfrankisk, slidt dragt af tykt, mørkt klæde. Den venstre arm var løftet og højre strakt ned. Han var dækket af et lag tørt, sprukkent ler, og på hans pande anedes et udhvisket tegn. En osende fakkel oplyste det lille sceneri, og midt i regnen hviskede manden Guds uudsigelige navn: $\mathrm{HVH}$ til en formløs masse, så der med ét fra hans hænder hang en marionetdukke af træ, en tro kopi af ham selv. Det var sagnet om Golem, han fortalte.

Rabbi Löw ledede i I500-tallet den jødiske menighed i Staronová. Rabbien var en lærd mand, der holdt af unge piger og kendte alverdens hundekunster, så da engang marodører ville angribe ghettoen og slå jøderne ihjel, skabte han efter hemmelige forskrifter i Talmud af en klump ler et kunstigt menneske, Golem, som angreb røverne og slog dem ned som fluer.

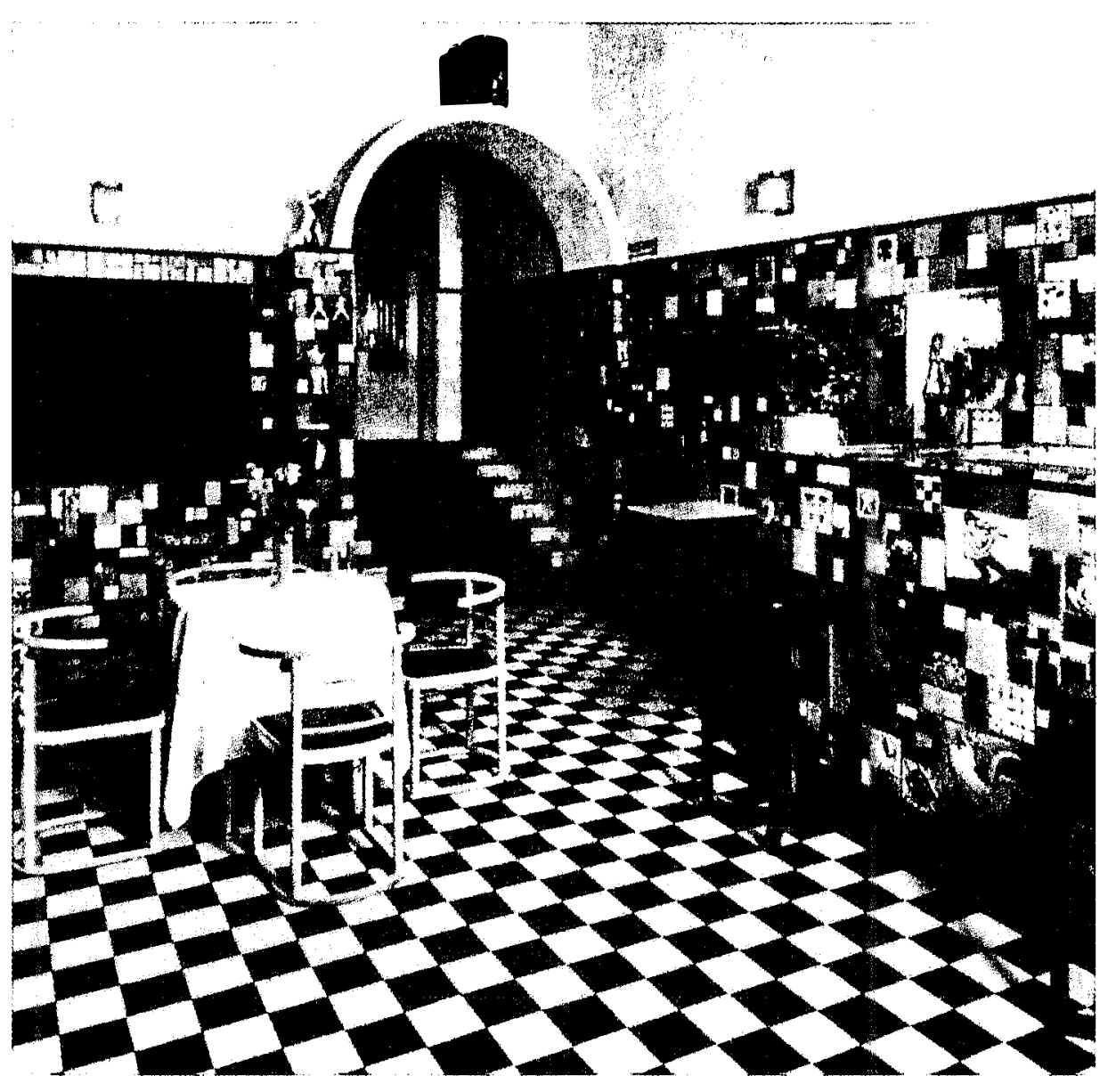


Jeg kastede et par mønter i skålen. Dukkeføreren kiggede tomt frem for sig, og jeg begav mig ind ad den forlængst sløjfede Hanefjedsgade, forbi marskandiseren Aaron Wasserturms kælderforretning og kunstgravørens værksted. Det regnede skomagerdrenge. Vandet slog op fra rendestenene, og jeg var allerede gennemblødt, da jeg så lys fra et værtshusvindue med rødt forhæng og afblegede fotografier af halvnøgne kvinder.

Et minut senere sad jeg med et glas cognac i Café Loisitschek. Et dansegulv med borde omkring. I baggrunden en estrade med trægelænder. En stærkt sminket pige med udslået hår lænede sig op ad det, hendes bryst var næsten nøgent, hun var iført korset, strømper og et par sko med meget høje hæle. Det var svært at skelne de andre skikkelser, men det var som om jeg kendte dem på forhånd: En smuk kvinde, som var lænket om håndleddene, i flænset musselinskjole, en hvidhåret gammel mand ved billardbordet, Ferri Athenstädt, den blinde olding Naphtali Schrafframeck med spilledåsen i sine skellethænder, studenten Charousek, dukkemageren Zwakh, den koparrede Loisa, hans døvstumme broder ... Midt på gulvet stod en kvinde, døddrukken med lukkede øjne, og vuggede til spilledåsens knirken. En kostbar hat med strudsefjer sad skævt på hendes hovede, det eneste hun havde på, var et par lange, rosafarvede strømper og en officersfrakke. Wasserturms datter, Rosina? Ana ...

"Frøken!". Servitricen, som hed Fritze, kom hen til mit bord. "Herren ønsker?". Jeg betalte og ville gå. "Hr. Pernath! Deres hat!” Jeg tog hatten og forsvandt ud på gaden. Regnen var hørt op og blæsten tilbage igen. Hr. Pernath!? Kunstgravøren i Hanefjedsgade hed Pernath ... Så er lyden der igen! Æterisk, som fra spinkle strenge. Tydelig. Den kommer fra kirkegården ved siden af synagogen. Inden for lågen, hvor gravstenene vælter rundt mellem hinanden, står den som en ønskesten på en af kantlisterne. Som et skellet, radmager, karryfarvet, med melankolske øjne og lang nøgen hale. En podengo. Vinden synger i dens ribben. Jeg kalder på den. Den ser

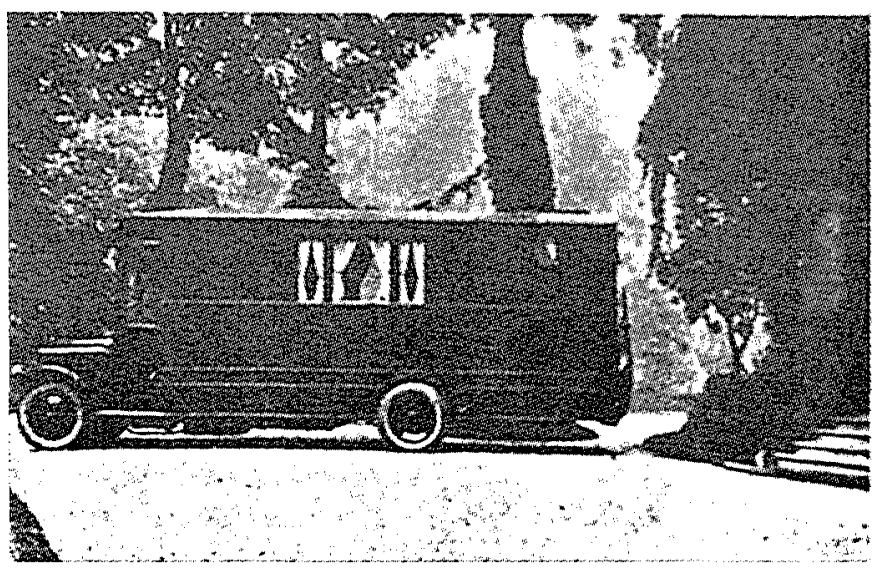


sørgmodigt på mig. "Kom så!” Den springer ned fra gravstenen og følger mig i behørig afstand ned mod floden, min odradek.

På Karlsbroen hørte jeg pludselig et råb. Det kom nedefra. Jeg lænede mig ud over cementkanten og fik øje på en båd af uhøvlede brædder med to personer: en færgemand, der roede over mod Hradschinbredden, og en passager, som stående forsøgte at holde balancen og samtidig vifte med armene: "Min hat!!". Hans ansigt var rettet mod mig, og det var som så jeg mig selv i et spejl. Meyerink. Gustav Meyerink. Jeg tog hatten af, stod med den $i$ hånden og læste $i$ gyldne bogstaver det fremmede og dog bekendte navn: “Athanasius Pernath". Kunstgravøren fra Hanefjedsgade, som engang for længe siden havde fảet forbyttet sin hat. Jeg kastede hatten ned til Meyerink, som greb den. Han satte den på hovedet, den passede perfekt, og vinkede. Jeg vinkede igen og gik barhovedet hjemad.

Hunden, som jeg kaldte Simba, fandt sig hurtigt tilrette på værelset og faldt i søvn med hovedet hvilende på min brune læderkuffert, hvis slidte skind med furer og sprækker ligner et gammelt kort, der forlængst har opgivet at finde vej. Jeg havde sat mig for at gøre et par notater, inden jeg gik til ro. På bordet lå Anas tomme, blåhvide cigaretpakke, SG lights. "Fumar pode matar", rygning kan forårsage døden. Rilke hævdede det enkelte menneskes ret til sin egen død, og hans forbillede var digteren Orfeus, som i sig selv forenede livets og dødens land.

"Jord er det ikke det ene du vil: usynligt opstå i os? ... jord! Usynlig! Hvad er om ikke forvandling det hverv du så mægtigt har lagt os på sinde?”

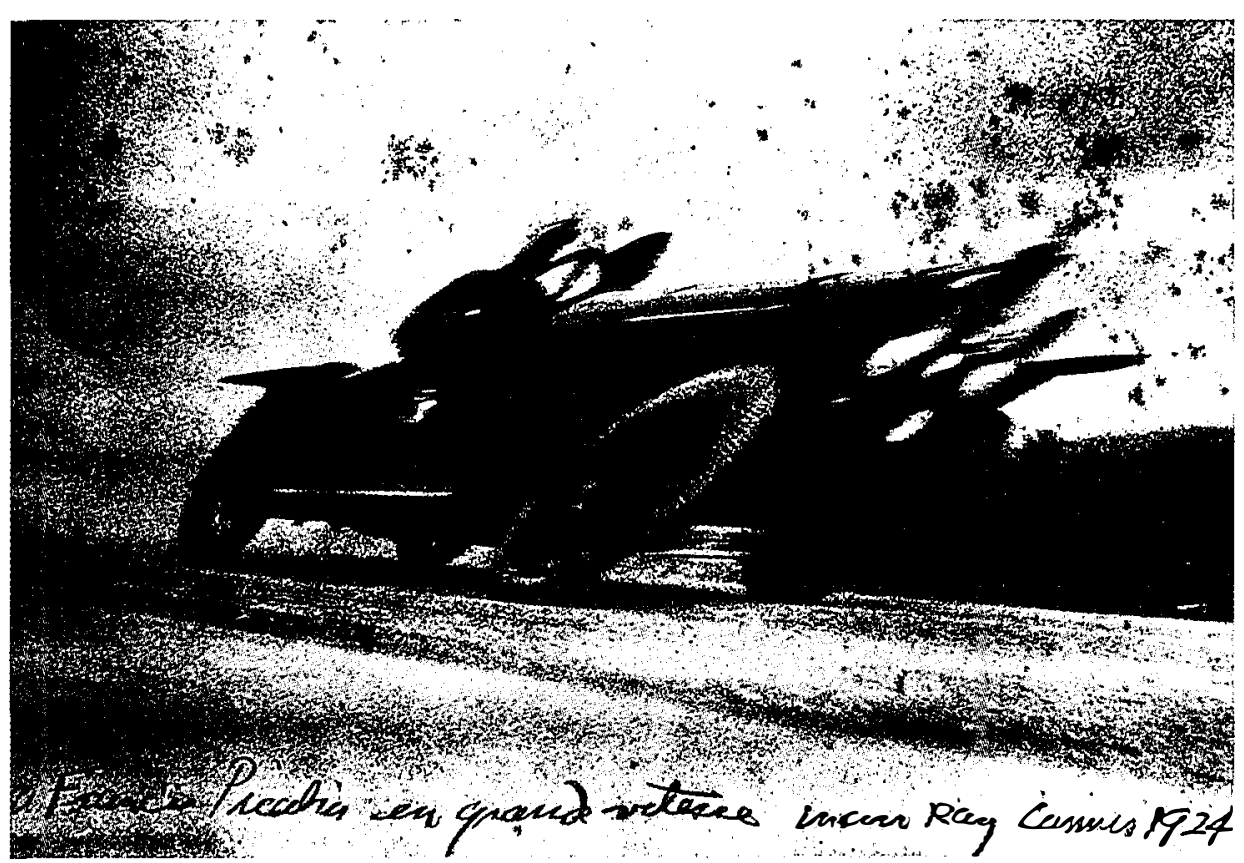

